\title{
超音波電子スキャン装置を用いた 逆散乱イメージング法の検証
}

\author{
中畑和之 $亡^{1}$ 松岡ちひろ $\cdot$ 廣瀬壮 $3^{3}$ \\ 1正会員 愛媛大学准教授 大学院理工学研究科生産環境工学専攻（† 790-8577 愛媛県松山市文京町 3) \\ 2 (研究当時) 学生会員 愛媛大学 大学院理工学研究科 (同上) \\ 3 正会員 東京工業大学教授 大学院情報理工学研究科情報環境学専攻（ $\bar{T} 152-8552$ 東京都目黒区大岡山 2-12-1）
}

\begin{abstract}
超音波アレイ探触子で得られる欠陥エコーを用いて，材料内部の欠陥形状を再構成する逆散乱イメージング 法が既往の研究1),2)によって提案されている. その逆散乱イメージング法には, ボルン近似およびキルヒホフ近 似を導入した 2 種類の手法があり，それぞれ欠陥の領域および境界を再構成することが数值シミュレーション によって示されている，本論文では，電子スキャン装置を用いて超音波計測を行い，逆散乱イメージング法の 実験的検証を行う。ここでは，ボイドを模擬した欠陥として横穴を，き裂を模擬した欠陥としてスリットをそれ ぞれアルミニウム試験体に作成し，これらの位置および形状の再構成を行った。電子スキャン装置で計測され た欠陥エコーを適切に波形処理することによって， 久陥形状が良好に再構成できることを示した。
\end{abstract} Key Words : phased array transducer, ultrasonic imaging, inverse scattering imaging method, elec-

\section{1. はじめに}

超音波アレイ探触子とは，独立に駆動できる複数の 小さな振動素子を直線状あるいは平面状に配置したセ ンサー3)である.この探触子は機械的に走査して久陥 エコーを収集する必要が無く, 電子的に駆動素子を切 り替えることによって瞬時に多点で欠陷エコーを得る ことが可能である.アレイ探触子を制御する超音波計 測装置は一般に電子スキャン装置と呼ばれており, 近 年では医療分野だけでなく工業分野においても電子ス キャン装置を用いた超音波非破壊検査が行われるよう になってきた4).

現在，超音波を用いて材料内部の欠陷形状を画像化 する一般的な手法は， B，Cスキャン5)である。これら は探触子を走査させながら欠陥からの欠陷エコーを計 測し，エコーの伝播時間と振幅值の関係を深さ方向に (B スキャン), またはある深さ位置における振幅值を平 面上に (Cスキャン) プロットしていく手法であり, 電 子スキャン装置を用いた超音波探傷でも, この手法が広 く用いられている. 一方, エコーの伝搬時間と振幅值だ けを利用するのでなく, エコーの波形情報 (位相，スペ クトル振幅等) を有効に活用し，これを計測位置の情報 と組み合わせることにより欠陥形状を高精度に再構成 する手法として, 逆散乱イメージング法1),2) が提案され ている. 逆散乱イメージング法は，フーリエ変換を基本 構造とした周波数領域開口合成法 $\left.{ }^{6)}, 7\right)$ (Fourier domain $\mathrm{SAFT})$ の理論を, 線形化逆散乱解析法 ${ }^{8)}$ に取り入れた
ものであり，検査対象とする材料の一計測平面で得ら れた欠陷エコーから, 久陷形状の再構成が可能である.

これまで，逆散乱イメージング法は境界要素法を用 いた数值シミュレーションによって, 欠陷画像化の可 能性が示されていた，そこで，本研究では，電子スキャ ン装置を用いて久陥からのエコーを実際に計測し，こ のエコーを用いて逆散乱イメージング法の検証を行う ことを目的とする. 計測されたエコーを用いて久陥を 画像化する際に考慮すべきことは，逆散乱イメージン グ法の入力值は欠陥からの散乱波成分であることであ る.ここで用いる “欠陥からの散乱波成分”とは, 具体 的には, 久陷からの散乱波がアレイ探触子の受信素子 に到達した際に生じる素子の変位を指している. 実際, アレイ探触子で受信されたエコーが電子スキャン装置 上でデジタル表示されるときには, 久陥からの散乱波 以外に, 探触子の周波数帯域, アンプによる増幅特性, 電気回路等のノイズ等によって変調された波形となっ ている. 従って, 本イメージング法では, これらの影 響を取り除き, 久陷からの散乱波成分を抽出する必要 がある。そこで, 本研究では電子スキャン装置で記録 される欠陥エコーから, 久陥からの散乱波成分を抽出 するためのデータ処理法を第 4 章で提案し, この処理 された波形データを逆散乱イメージング法に適用する ことによって久陥形状の再構成を行う。ここで提案す るデータ処理法は，参照波を用いたデコンボリューショ ン処理 $\left.{ }^{9}\right)$ 基づくものである. 本実験で用いるアレイ探 触子の 1 つ素子の大きさは欠陷と同オーダーであり, 
この素子のモデル化が画像化の精度に大きく左右する ため, ここでは 1 つ素子が生成するビームプロファ イルを厳密にモデル化したデータ処理法を採用してい るのが特徴である。

なお，久陥エコーから抽出した散乱波成分に着目し， これを非破壊評価に用いることは，過去の研究でもい くつか見られる. 本研究のように, 欠陥の画像化が目 的でなないが，例えば国内では，二ューラルネットワー クを併用することで, き裂の高さ推定を試みた高堂谷 らの研究10)がある.

筆者らの前論文 ${ }^{1)}$ では，面外波 (SH 波) を送受信する 場合の逆散乱イメージング法の理論, および数值シミュ レーションによる久陷画像化の例が示されている。しか しながら，本研究で用いる電子スキャン装置は縦波超 音波を送受信するアレイ探触子を用いるため，第 2 章 では, 逆散乱イメージング法の縦波モードの定式化を 簡単に述べる. また, 本イメージング法の解像度につ いても言及する。また, 実験による欠陥の再構成結果 と比較するために, 第 3 章では, 境界要素法による計 算波形を用いたシミュレーションを示す.

\section{2. 逆散乱イメージング法}

\section{（1）波動場の設定と定式化}

本イメージング法で対象とする超音波の送受信の概 念図を図-1に示す. 均質等方な弾性体 $D$ 内に散乱体 (欠陥) $D^{c}$ が存在しているものとする.アレイ探触子の 1 つの振動素子 $\boldsymbol{y}$ から縦波 $\boldsymbol{u}^{\text {in }}$ 大射し, 欠陥 $D^{c}$ に よって散乱された波動 $\boldsymbol{u}^{\mathrm{sc}}$ を同じ素子で受信したとし て，その送受信を全ての素子について行い，得られた 散乱波形から逆に久陥の形状を推定する. 角振動数を $\omega$ とする定常波動場において, 点 $\boldsymbol{y}$ における欠陷による 散乱波は次のように表される8).

$$
u_{m}^{\mathrm{sc}}(\boldsymbol{y}, \omega)=\int_{D} U_{i m}(\boldsymbol{x}, \boldsymbol{y}, \omega) q_{i}(\boldsymbol{x}, \omega) d V(\boldsymbol{x})
$$

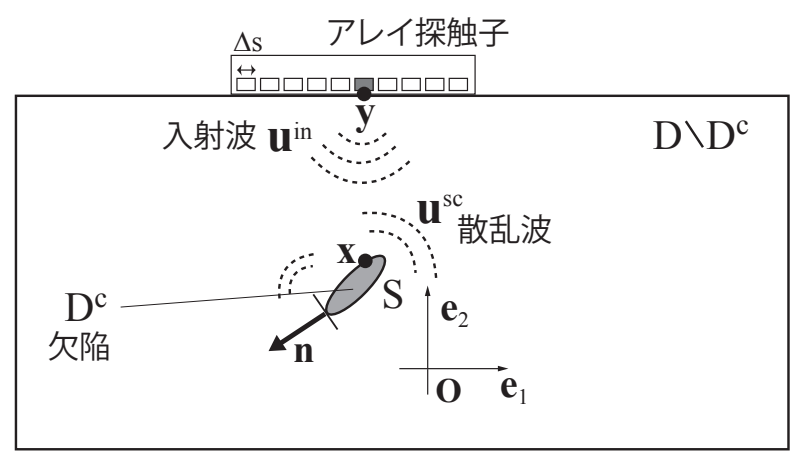

図-1 逆散乱イメージング法における超音波の送受信概要
ここで, $\boldsymbol{U}(\boldsymbol{x}, \boldsymbol{y}, \omega)$ は 2 次元面内波動問題の基本解で あり, 以下のように書ける。

$$
\begin{aligned}
U_{i m}(\boldsymbol{x}, \boldsymbol{y}, \omega)=\frac{\mathrm{i}}{4 \mu} & {\left[H_{0}^{(1)}\left(k_{T} r\right) \delta_{i m}+\frac{1}{k_{T}^{2}} \frac{\partial^{2}}{\partial x_{i} \partial x_{m}}\right.} \\
& \left.\times\left\{H_{0}^{(1)}\left(k_{T} r\right)-H_{0}^{(1)}\left(k_{L} r\right)\right\}\right]
\end{aligned}
$$

ここで, $r=|\boldsymbol{x}-\boldsymbol{y}|, k_{L}$ と $k_{T}$ はそれぞれ縦 $(\mathrm{L})$ 波と 横 $(\mathrm{T})$ 波の波数である. 本イメージング法では, アレ イ探触子の真下に欠陥が存在するものとし, それらの 距離は L 波と $\mathrm{T}$ 波が分離できる程度に遠方であると仮 定する. 従って, 後の定式化で必要となる式 (2)の遠方 表現を記しておく. $z$ が大きい場合, ハンケル関数は次 式のように近似できる。

$$
H_{0}^{(1)}(z) \approx \sqrt{\frac{2}{\mathrm{i} \pi z}} \exp (\mathrm{i} z)
$$

上式を式 (2) に代入すると次式を得る。

$$
\begin{aligned}
U_{i m}^{\mathrm{far}}(\boldsymbol{x}, \boldsymbol{y}, \omega) \approx \frac{\mathrm{i}}{4 \mu} & {\left[\left(\delta_{i m}-d_{i} d_{m}\right) \sqrt{\frac{2}{\mathrm{i} \pi k_{T} r}} \exp \left(\mathrm{i} k_{T} r\right)\right.} \\
& \left.+\left(\frac{k_{L}}{k_{T}}\right)^{2} d_{i} d_{m} \sqrt{\frac{2}{\mathrm{i} \pi k_{L} r}} \exp \left(\mathrm{i} k_{L} r\right)\right]
\end{aligned}
$$

ここで $\boldsymbol{d}=(\boldsymbol{x}-\boldsymbol{y}) / r$ である. 式 (1) における $\boldsymbol{q}$ は等価 散乱源であり, 欠陥形状を表す関数を含んでいる。等 価散乱源は 2 通りに表すことができ, 領域型の積分表 現に対応した等価散乱源は

$$
\begin{aligned}
q_{i}^{\Gamma}(\boldsymbol{x}, \omega)=\Gamma(\boldsymbol{x}) & \left\{\Delta \rho \omega^{2} u_{i}(\boldsymbol{x}, \omega)\right. \\
& \left.-\Delta C_{i j k l} u_{k, l}(\boldsymbol{x}, \omega) \partial / \partial x_{j}\right\}
\end{aligned}
$$

である. 上式で, $\Delta C_{i j k l}$ は母材 $D$ と欠陥 $D^{c}$ の弾性 定数の差を表すテンソルであり, 本手法では等方性弾 性体を仮定しているので, ラメ定数 $\lambda$ と $\mu$ を用いて, $\Delta C_{j k l m}=\Delta \lambda \delta_{j k} \delta_{l m}+\Delta \mu\left(\delta_{j m} \delta_{k l}+\delta_{j l} \delta_{k m}\right)$ と表すこ とができる。また， $\Delta \rho$ は母材と欠陥の密度差を表す物 理量である. 式 (5) 中の $\Gamma$ は欠陥 $D^{c}$ の領域内部におい てのみ值を有する特性関数であり, 次式で定義される.

$$
\Gamma(\boldsymbol{x})= \begin{cases}1 & \boldsymbol{x} \in D^{c} \\ 0 & \boldsymbol{x} \in D \backslash D^{c} .\end{cases}
$$

次に, 境界型の積分表現に対応した等価散乱源は次 のようになる。

$$
\begin{aligned}
q_{i}^{\gamma}(\boldsymbol{x}, \omega)=-\gamma(\boldsymbol{x}) C_{i j k l} & \left\{n_{j}(\boldsymbol{x}) u_{k, l}(\boldsymbol{x}, \omega)\right. \\
& \left.-n_{l}(\boldsymbol{x}) u_{k}(\boldsymbol{x}, \omega) \partial / \partial x_{j}\right\}
\end{aligned}
$$

ここで， $\boldsymbol{n}$ は欠陥境界から母材に向く法線ベクトルで ある. 式 (7) 中の $\gamma$ は欠陷の境界 $S$ 上においてのみ值 を有する特異関数であり, 次式で定義される.

$$
\int_{D} \gamma(\boldsymbol{x}) d V(\boldsymbol{x})=\int_{S} d S(\boldsymbol{x}) .
$$

いま，ある素子の接触面 $\Delta s$ の上で一様な表面力 $\boldsymbol{t}$ を 励起することによって超音波が発生するものとすれば, 
欠陥に入射する波は次のように表現できる.

$$
\begin{array}{r}
u_{m}^{\mathrm{in}}(\boldsymbol{x}, \omega)=\int_{\Delta s} U_{i m}^{\mathrm{far}}(\boldsymbol{y}, \boldsymbol{x}, \omega) t_{i}(\boldsymbol{y}, \omega) d S(\boldsymbol{y}) \\
\simeq U_{i m}^{\mathrm{far}}\left(\boldsymbol{y}_{0}, \boldsymbol{x}, \omega\right) t_{i}\left(\boldsymbol{y}_{0}, \omega\right) \Delta s
\end{array}
$$

ここで， $y_{0}$ は素子の接触面の代表点である．縦波を送 受信するため, 探触子の振動方向は接触面に垂直であ る. 従って, $\boldsymbol{t}$ の振動方向と基底べクトル $e_{2}$ は平行であ り, 上述の探触子と欠陥の位置関係の仮定より $\boldsymbol{d}$ も れらに平行であると仮定する。また, 波動の線形性に則 れば，探触子の励起振動の大きさは画像化結果には影響 しない. 以上より, 次元を考慮して $\boldsymbol{t}=\mu \boldsymbol{d} \approx \mu\left(-\boldsymbol{e}_{2}\right)$ で探触子を励起するものとすれば，上式は

$$
\begin{aligned}
u_{m}^{\mathrm{in}}(\boldsymbol{x}, \omega) & =\mathrm{i} u^{0} d_{m} \sqrt{\frac{2}{\mathrm{i} \pi k_{L} r}} \exp \left(\mathrm{i} k_{L} r\right) \\
& =-\mathrm{i} u^{0}\left(\boldsymbol{e}_{2}\right)_{m} \sqrt{\frac{2}{\mathrm{i} \pi k_{L} r}} \exp \left(\mathrm{i} k_{L} r\right)
\end{aligned}
$$

と書ける.ここで, $u^{0}=\frac{1}{4}\left(\frac{k_{L}}{k_{T}}\right)^{2} \Delta s$ とおいた。

次に，低周波域および高周波域で有効とされるボルン 近似とキルヒホフ近似を用いて, 式 (1) を線形化する. ボルン近似は, 式 (5) に含まれる変位場 $\boldsymbol{u}$ を式 (10) で

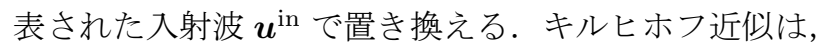
式 (7) 中の境界上の変位場 $\boldsymbol{u}$ を, 入射波 $\boldsymbol{u}^{\mathrm{in}}$ とその到達 点における反射波の和で置き換える. 面内波動場におけ る逆散乱問題の線形化のための具体的な数式の展開は筆 者らの前論文 ${ }^{11)}$ を参考にされたい. なお，本手法の定式 化の過程で, 線形化のため, 次の近似: $1 / \sqrt{r} \approx 1 / \sqrt{\left|y_{2}\right|}$ を用いた。この近似は, 久陥がアレイ探触子の真下に ある場合に有効に作用する．最終的にフーリエ変換構 造に帰着する逆解析のプロセスは SH 波の場合と同じ である。

ボルン逆散乱イメージング法の最終フォームは次の ようになる。

$\bar{A}\left(k_{1}, y_{2}, \omega\right)$

$=\frac{-2 u^{0} k_{L}^{2}}{\sqrt{\mathrm{i} \pi k_{L}\left|y_{2}\right|}} \frac{\exp \left(\mathrm{i} \sqrt{4 k_{L}^{2}-k_{1}^{2}} y_{2}\right)}{\sqrt{4 k_{L}^{2}-k_{1}^{2}}} \tilde{\Gamma}\left(k_{1}, \sqrt{4 k_{L}^{2}-k_{1}^{2}}\right)$

ここで, $\tilde{\Gamma}$ は $\Gamma$ の 2 次元フーリエ変換

$\Gamma\left(x_{1}, x_{2}\right)$

$=\frac{1}{(2 \pi)^{2}} \iint_{-\infty}^{\infty} \tilde{\Gamma}\left(k_{1}, k_{2}\right) \exp \left[\mathrm{i}\left(k_{1} x_{1}+k_{2} x_{2}\right)\right] d k_{1} d k_{2}$

である。式 (11) 中において, $\bar{A}\left(k_{1}, y_{2}, \omega\right)=$ $\overline{\boldsymbol{u}}^{\mathrm{sc}}\left(k_{1}, y_{2}, \omega\right) \cdot \boldsymbol{e}_{2}$ であり, 散乱波の $y_{2}$ 方向成分 を表す. なお, 関数の上付きの一は, 以下のような 1 次 元フーリエ変換後の関数を表している.

$\bar{\Psi}\left(k_{1}, y_{2}, \omega\right)=\int_{-\infty}^{\infty} \Psi\left(y_{1}, y_{2}, \omega\right) \exp \left(-\mathrm{i} k_{1} y_{1}\right) d y_{1}$
式 (11) からわかるように, $\boldsymbol{u}^{\mathrm{sc}}$ の $y_{2}$ 方向成分を計測し, これより得られた計測データ $\bar{A}\left(k_{1}, y_{2}, \omega\right)$ から, 特性関 数 $\Gamma\left(x_{1}, x_{2}\right)$ のフーリエ変換 $\tilde{\Gamma}$ が求まる. このとき, $\tilde{\Gamma}$ が得られる点の集合は $\left(k_{1}, \sqrt{4 k_{L}^{2}-k_{1}^{2}}\right)$ となる.すな わち，図-2の上側に示守より $\boldsymbol{K}$-空間において，半 径 $2 k_{L}$ の円周上で $\tilde{\Gamma}$ の值が求められることになる. 送 信する超音波の波数 (周波数) を変えることによって, 波数に応じた半径 $2 k_{L}$ の円周上に $\tilde{\Gamma}$ がプロットされて いく (図-2下側). 試験体の上側に置かれたアレイ探触 子で計測されたエコーからは $\boldsymbol{K}$-空間の上半面の $\tilde{\Gamma}$ (実 線) が構成される. 試験体の下側にもアレイ探触子が配 置されれば， $\boldsymbol{K}$-空間の下半面の $\tilde{\Gamma}$ (破線) も得られる. 最終的に, $\boldsymbol{K}$-空間上において最大周波数 $2 k_{L}^{\max }$ までの 範囲で $\tilde{\Gamma}$ が得られるので，これを式 (12) によってフー リエ変換すれば欠陥の領域形状 $\Gamma(\boldsymbol{x})$ が再構成されるこ とになる.

また，キルヒホフ逆散乱イメージング法における $\bar{A}$ と $\tilde{\gamma}$ の関係は次のようになる.

$\bar{A}\left(k_{1}, y_{2}, \omega\right)$

$=\frac{-2 \mathrm{i} u^{0} k_{L}}{\sqrt{\mathrm{i} \pi k_{L}\left|y_{2}\right|}} \frac{\exp \left(\mathrm{i} \sqrt{4 k_{L}^{2}-k_{1}^{2}} y_{2}\right)}{\sqrt{4 k_{L}^{2}-k_{1}^{2}}} \tilde{\gamma}\left(k_{1}, \sqrt{4 k_{L}^{2}-k_{1}^{2}}\right)$

ボルン逆散乱イメージング法と同様に，これをフーリ エ変換すれば, $\gamma\left(x_{1}, x_{2}\right)$ が得られる.

$$
\begin{aligned}
& \gamma\left(x_{1}, x_{2}\right) \\
& =\frac{1}{(2 \pi)^{2}} \iint_{-\infty}^{\infty} \tilde{\gamma}\left(k_{1}, k_{2}\right) \exp \left[\mathrm{i}\left(k_{1} x_{1}+k_{2} x_{2}\right)\right] d k_{1} d k_{2}
\end{aligned}
$$

キルヒホフ逆散乱イメージング法の線形化に用いた近 似の性質はボルン逆散乱イメージング法のそれとは全 く異なるが, 最終的な形はボルン逆散乱イメージング 法と係数倍を除いて同じである.しかし，この係数の 違いが, 久陥の領域を再構成するか, 境界部を再構成 するかに大きく関わってくる.

\section{(2) 解像度}

2 次元高速フーリエ変換 $(2-\mathrm{D} \mathrm{FFT})$ を用いれば式 $(12)$ と式 (15) は高速に計算することができる. 2-D FFTを $\boldsymbol{K}$-空間に適用するための離散化およびデータ配置の方 法については, 筆者らの前論文 $\left.{ }^{12}\right)$ にって詳細が示さ れている.

図-2の下側に示したように，イメージングに必要と なる波形データは半径 $2 k_{L}^{\max }$ の円形の領域にプロットさ れている. なお，アレイ探触子が試験体の上部のみに設 置される場合には $\boldsymbol{K}$-空間において $k_{2}<0$ の波形デー 夕は得られないため, 数值解析の便宜上, $\tilde{\Gamma}\left(k_{1}, k_{2}\right)=$ $\tilde{\gamma}\left(k_{1}, k_{2}\right)=0\left(k_{2}<0\right)$ とする. 2-D FFT を適用する 
場合には有限の離散データを扱うことから，図-2の下 側の塗りつぶした 4 角形の範囲のデータが実際に用い られる. すなわち， $k_{1}$ の積分範囲は $-k_{1}^{\max }$ から $k_{1}^{\max }$ であり， $k_{2}$ は $-k_{2}^{\max }$ から $k_{2}^{\max }$ となる.この $k_{1}^{\max }$ は, 式 (13) を 1-D FFT を用いて実行するときに決定され る.すなわち, ナイキスト数の制約から $k_{1}$ に関する 積分範囲の最大值は素子の間隔 (ピッチ) $\Delta y_{1}$ に依存し, $k_{1}^{\max }=\pi / \Delta y_{1}$ となる. また, $k_{2}$ に関する積分範囲の最 大值は, $k_{2}^{\max }=\sqrt{4\left(k_{L}^{\max }\right)^{2}-\left(k_{1}^{\max }\right)^{2}}$ で決定される.

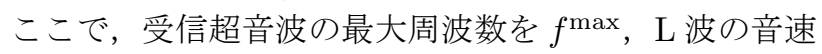
を $c_{L}$ と書けば, $k_{L}^{\max }=2 \pi f^{\max } / c_{L}$ である. 従って, $2 \mathrm{D}$-FFT を用いて $\boldsymbol{K}$-空間 $\left(k_{1}, k_{2}\right)$ から実空間 $\left(x_{1}, x_{2}\right)$ を求めるとき, 再構成される画素の大きさ (解像度) は, $\Delta x_{i}=\pi / k_{i}^{\max }, \quad(i=1,2)$ で決定され, $x_{1}$ 方向の解像 度はアレイ探触子の間隔 $\Delta y_{1}$ に, $x_{2}$ 方向は受信波の周 波数 $f^{\max }$ によって決定されることがわかる.

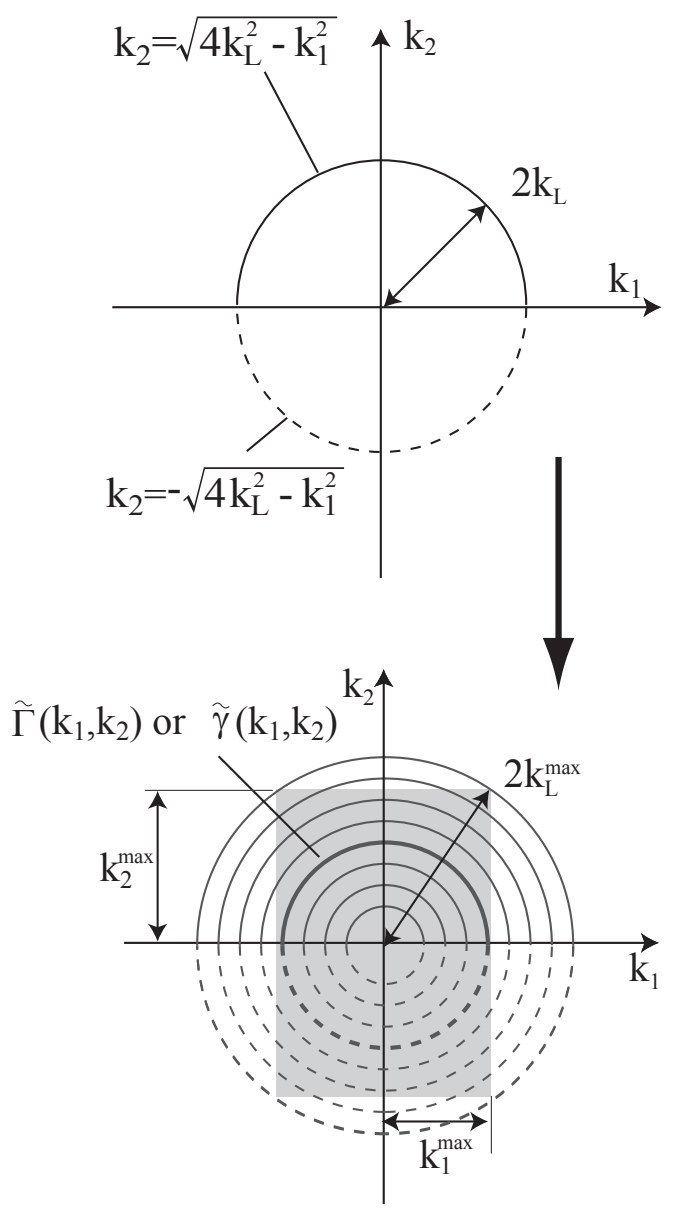

図-2 $\boldsymbol{K}$-空間に集められた散乱波データ $\tilde{\Gamma}$ と $\tilde{\gamma}$ ，および $2-\mathrm{D}$ FFT のためのデータサンプリングエリア (塗りつぶし 領域)

\section{3. 数値シミュレーションによる欠陥の再構 成結果}

ここでは，次章で示す電子スキャン装置で得られる 計測波形を用いた場合の再構成結果と比較するために， 境界要素法を用いて数值的に作成した散乱波を用いて 久陷像の再構成を行った結果を示しておく. 数值解析 には実験で用いる試験体と同じ材料を仮定し，欠陥形 状やアレイ探触子の素子配置等の仕様も同じように設 定している.

図-3の上図に示すように，平らな表面をもつアルミ ニウム $\left(c_{L}=6360 \mathrm{~m} / \mathrm{s}, \rho=2700 \mathrm{~kg} / \mathrm{m}^{3}\right)$ とし, その内 部に直径 $2 \mathrm{~mm}$ の円形空洞が深さ方向に互いにずれて 5 つ存在する欠陥モデルを考える. 3 番目に深い欠陥の中 心は試験体表面から真下に $40 \mathrm{~mm}$ であり，欠陥はすべ て等間隔で並んでいる. アレイ探触子は幅 $0.7 \mathrm{~mm}$ の素 子がピッチ $0.8 \mathrm{~mm}$ 間隔で 64 個配列したものを模擬し ており，超音波は 1 素子ずつ L 波を送受信するものと する.

図-3 の下側に，ボルンおよびキルヒホフ逆散乱イメー ジング法による久陥の再構成結果を示す. イメージン グ領域は 3 番目に深い空洞を中心として $40 \mathrm{~mm} \times 40 \mathrm{~mm}$ の範囲をプロットしている. ボルン逆散乱イメージン グ法は欠陥の領域形状を表す特性関数 $\Gamma(\boldsymbol{x})$ を, キルヒ ホフ逆散乱イメージング法は欠陥の境界形状を表す特 異関数 $\gamma(\boldsymbol{x})$ を再構成するため, 再構成図ではこれらの 関数に濃淡をつけてプロットしている.なお，イメー ジング結果はそれぞれの関数值の最大值で割ることに よって正規化している. 再構成に用いた最大周波数は $f^{\max }=6.0 \mathrm{MHz}$ である. アレイ探触子を試験体の上側片 面に設置し, 超音波の送受信を行っているため, 両図 とも, 空洞欠陥の上側部分がイメージングされている のがわかる。また, 試験体の表面から離れた深い位置 の欠陥は，表面近くの欠陥に比べて久陥形状がぼやけ ており，感度が低いことがわかる。

\section{4. 計測実験の装置概要とデータ処理法}

\section{(1)＼cjkstart電子スキャン装置とアレイ探触子}

超音波アレイ探傷実験のための計測装置を図-4 に示 す.ここでは, 日立エンジニアリングアンドサービス 製の超音波電子スキャン装置 (ES3100) を用いて久陥エ コーを計測した. ES3100では, 久陥エコーのホワイト ノイズを軽減するために，10 回連続でデータ収録を行 い，その平均を計測データとして記録している。実験 で使用したアレイ探触子を図-4 (b) に示す.この探触 子は KGK 社製の公称中心周波数が $2 \mathrm{MHz}$ のものであ り，素子幅は $0.7 \mathrm{~mm}$, ピッチは $0.8 \mathrm{~mm}$, 奥行き長さは 


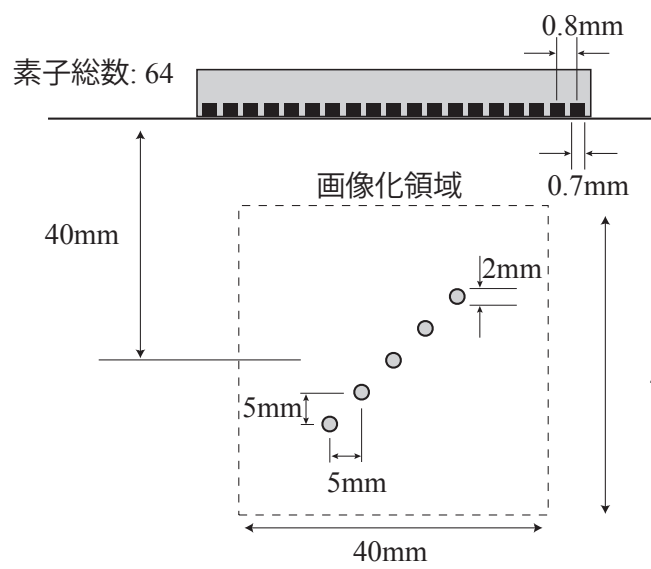

$40 \mathrm{~mm}$
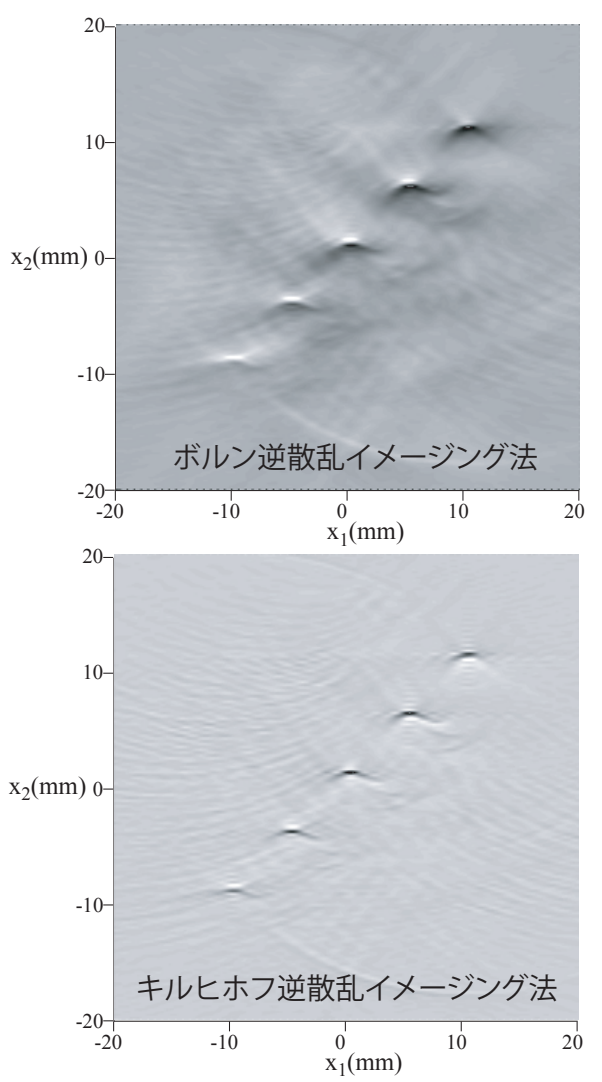

図-3 境界要素法による数值解析によって得られた散乱波を 用いた場合の久陥の再構成像

$18 \mathrm{~mm}$ である. この探触子の任意の 1 素子を駆動して， アルミニウム試験体の底面からのエコーを計測したと きの時間域波形とそのフーリエスペクトルを図-5に示 す. 図-5より，ピーク周波数は $2.3 \mathrm{MHz}$ であることが わかる。実験では，アレイ探触子を直接試験体に接触 させて超音波を送受信しており，アレイ探触子と試験 体の接触媒質としてグリセリンペースト (ソニコート) を使用した。

\section{（2）データ処理方法}

逆散乱イメージング法は, 久陷からの散乱波成分 (具 体的には，探触子位置 $\boldsymbol{y}$ で計測される変位の $y_{2}$ 方向成

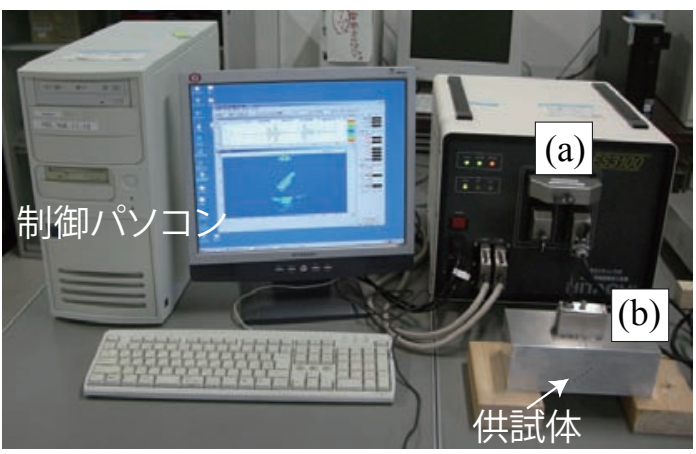

(a) 電子スキャン装置

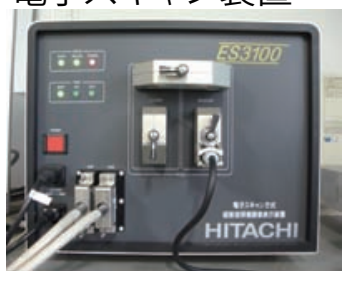

(b) アレイ探触子

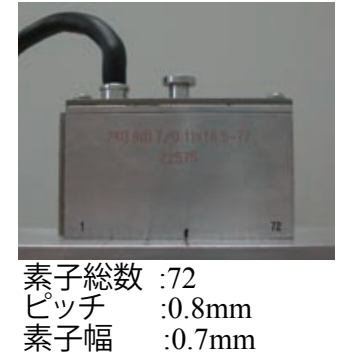

図-4 電子スキャン装置とアレイ探触子
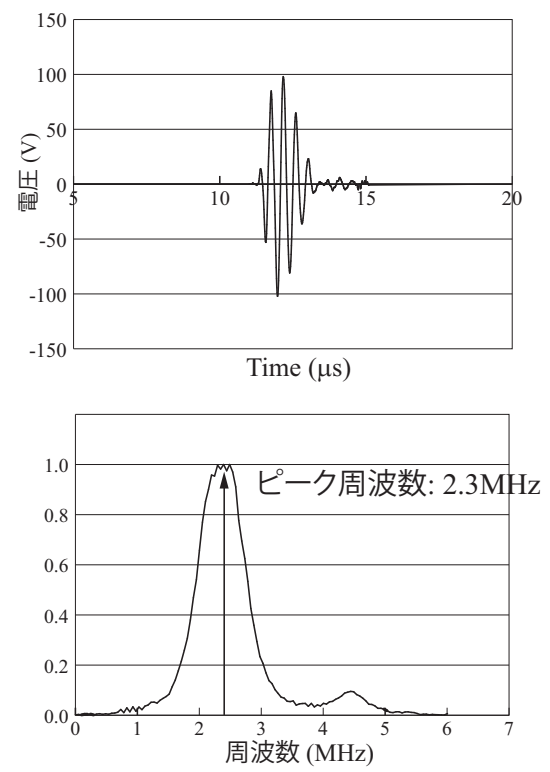

図-5 アルミニウム試験体からの底面エコーとそのフーリエ スペクトル

分) を基に欠陥像を再構成する. しかし, 電子スキャン 装置で計測された欠陥エコーには, 探触子の周波数帯 域, アンプによる増幅特性, 電気回路等のノイズ等, 欠 陥からの散乱波以外の要素も含まれている，従って，電 子スキャン装置で計測された欠陥エコーをそのまま逆 散乱イメージング法のインプットとして用いるのは適 切ではない。 そこで，本節では欠陥から散乱波成分を 抽出するためのデータ処理方法について述べる. 
図-6の上側に示すように，電子スキャン装置の画面 上に表示される欠陥エコー $V^{\text {out }}(t)$ は，種々の影響関数 を用いて表すことができる。

$V^{\text {out }}(t)=M(t) \otimes P_{1}(t) \otimes P_{2}(t) \otimes C_{1}(t) \otimes C_{2}(t) \otimes S(t)$

ここで， $\otimes$ は時間に関する合成積を表し， $M(t)$ はアレ イ探触子の周波数特性等を含む電子スキャン装置に関 する影響関数， $P_{1}$ と $P_{2}$ は送信経路 $[1]$ および受信経路 [2] における超音波ビームの伝搬距離, $C_{1}$ と $C_{2}$ は超音 波ビームの回折補正， $S$ は欠陥による散乱波成分を表し ている．計測系の線形性を仮定すると， $V^{\text {out }}(t)$ はフー リエ変換域 (周波数域) で以下のような単純積で書き表 すことができる.

$$
V^{\text {out }}(\omega)=M(\omega) P_{1}(\omega) P_{2}(\omega) C_{1}(\omega) C_{2}(\omega) S(\omega)
$$

ここで，逆散乱イメージング法のインプットとなる散 乱波成分は $A(\boldsymbol{y}, \omega) \approx P_{1}(\omega) P_{2}(\omega) C_{1}(\omega) C_{2}(\omega) S(\omega)$ と 見なすことができる.よって, 式 (17) を書き直すと,

$$
V^{\text {out }}(\omega)=M(\omega) A(\boldsymbol{y}, \omega)
$$

となる。

上式の $M(\omega)$ を解析的に決定するのは困難であるの で，ここでは参照波を用いたデコンボリューションに よって $A$ を抽出する. 参照波は図一6の下側のように， 深さ $D$ の金属片の上部にアレイ探触子を設置した場合 に得られる底面の反射エコーである．参照波は周波数 領域で次のように表すことができる.

$$
V^{\mathrm{ref}}(\omega)=M(\omega) \exp \left(2 i k_{L} D\right) C_{1}^{\prime}(\omega) C_{2}^{\prime}(\omega) R(\omega)
$$

ここで， $R$ は音響インピーダンスで定義される反射係数 であり， $C_{1}^{\prime}$ と $C_{2}^{\prime}$ の回折補正の表現については Schmerr と Song が理論式9)を示している. 欠陥エコーの式 (18) を参照波の式 (19) で割ることによって，固体内の散乱 波成分 $A$ は次のようなデコンボリューション処理によっ て抽出できる.

$A(\boldsymbol{y}, \omega)=\frac{V^{\mathrm{out}}(\omega)}{V^{\mathrm{ref}}(\omega)} \exp \left(2 i k_{L} D\right) C_{1}^{\prime}(\omega) C_{2}^{\prime}(\omega) R(\omega)$

ここで, $\frac{V^{\mathrm{out}}(\omega)}{V^{\mathrm{ref}}(\omega)}$ を計算するときに注意が必要である. 探触子は一般的には周波数領域で共振ピークをもって おり，共振から外れた周波数帯域では $V^{\text {out }}$ と $V^{\text {ref }}$ は 共に值が 0 に近くなる.つまり， $\frac{V^{\text {out }}(\omega)}{V^{\text {ref }}(\omega)}$ は $\frac{0}{0}$ の計算 を行う危険性をはらんでいる。これを避けるために，こ こでは Wiener filter ${ }^{13)}$ を援用する。これを用いれば,

$$
\frac{V^{\text {out }}(\omega)}{V^{\text {ref }}(\omega)}=\frac{V^{\text {out }}(\omega) V^{\text {ref }}(\omega)^{*}}{\left|V^{\text {ref }}(\omega)\right|^{2}+\varepsilon^{2} \max \left\{\left|V^{\text {ref }}(\omega)\right|^{2}\right\}}
$$

と表すことができる。上式で＊は複素共役を表す。ま た，とはフィルタパラメータであり，本論文では種々の 試行の結果から $\varepsilon=0.01$ を採用している. また，実際に
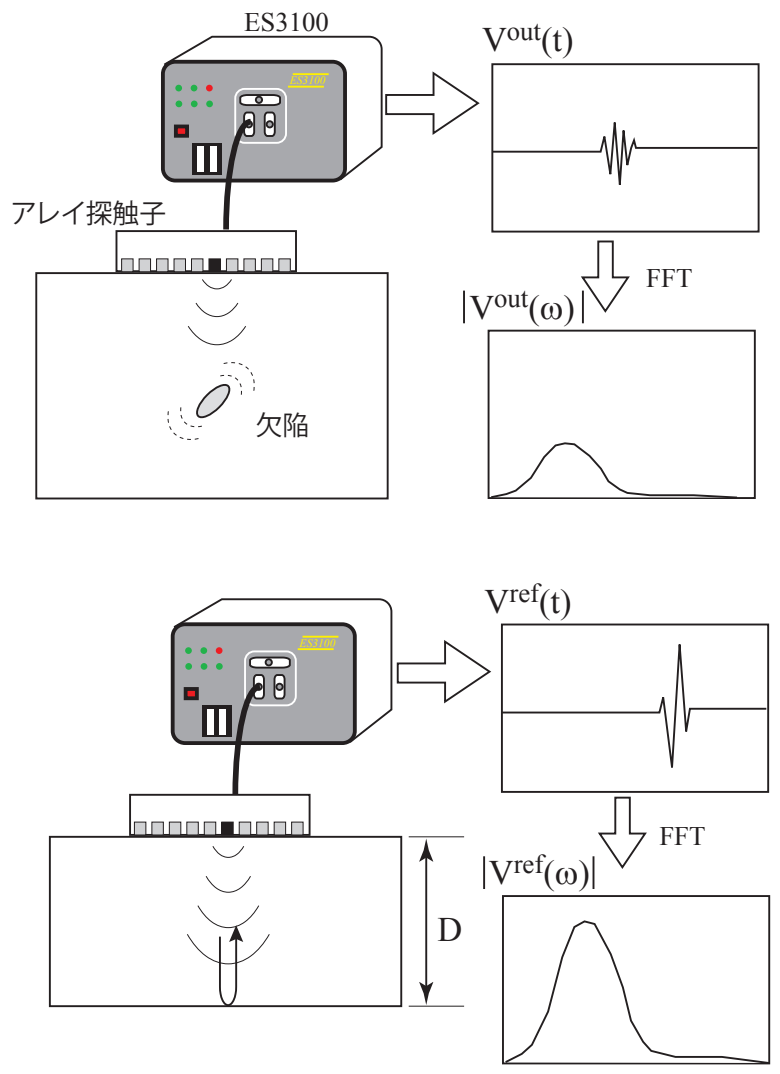

図-6 欠陥エコー $V^{\text {out }}$ と参照波 $V^{\mathrm{ref}}$

式 (20) を用いる場合には，欠陥からの散乱波が到達す る時刻の前後で波形を切り出している.

\section{5. 計測波形による欠陥の再構成結果}

\section{（1）空洞欠陥の再構成}

試験体として，図-7 の上図に示すようなアルミニウ ムの内部に直径 $2 \mathrm{~mm}$ の貫通横穴を 5 つ作成した。試験 体の上側にアレイ探触子を設置し，超音波の送受信を 1 素子ずつ順次切り替えることによって, 計 64 素子で 計測を行った。計測された欠陥エコーに前節で示した データ処理を施して散乱波成分を抽出し，これを逆散 乱イメージング法にインプットすることによって久陥 像の再構成を行った。再構成に使用した超音波の周波 数帯域は $0.1 \mathrm{MHz} \sim 5.0 \mathrm{MHz}$ とした. なお, 最大周波数 の $5.0 \mathrm{MHz}$ に対応するアルミニウム中の超音波の波長 は約 $1.3 \mathrm{~mm}$ であり，横穴の直径よりも小さい.

図-7 の下側にボルンおよびキルヒホフ逆散乱イメー ジング法による再構成結果を示す。電子スキャン装置 で計測された欠陥エコーを使って，試験体内部の欠陥 形状を精度良く再構成できることがわかる，図-3に示 す数值シミュレーションによる結果と比較して, 計測 実験の欠陥像は若干大きめに再現されているが，これ は本実験で使用したアレイ探触子が $2.3 \mathrm{MHz}$ をピーク 

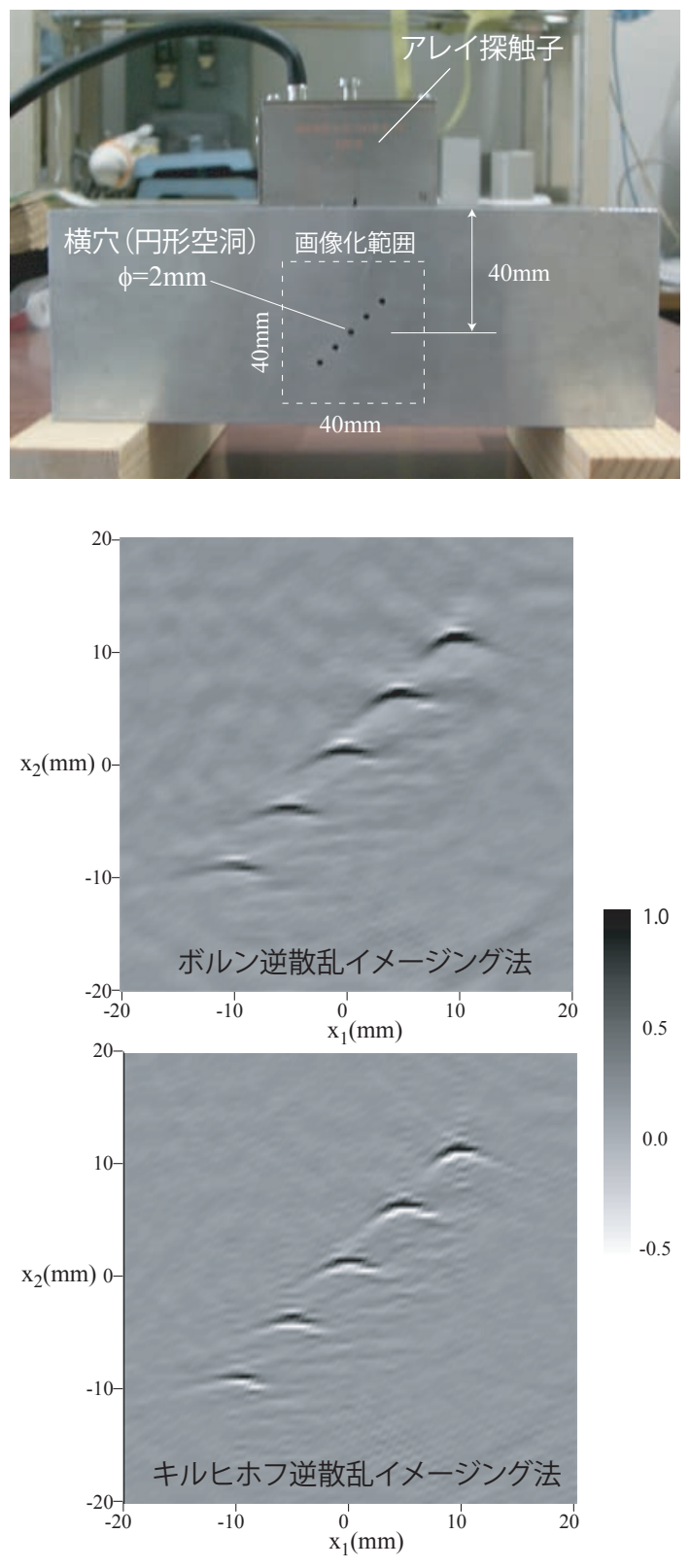

図-7 電子スキャン装置を用いた空洞欠陥の形状再構成

とした有限の周波数帯域であり, シミュレーションに 比べて高周波成分が欠如していることが原因であると 思われる。

\section{(2) スリットの再構成}

き裂は溶接部などで多く発生し, 材料の破断を防止 するためにも, き裂の検出・評価は重要である.ここ では, き裂を模擬して, 図-8 亿示すような傾き $\theta$ の異 なる 4 つの貫通スリットをアルミニウム試験体に作成 した，アレイ探触子は前節と同じものを使用し，欠陥 の画像化に使用した超音波の周波数帯域も同様とした. まず，アレイ探触子を各スリットの真上に設置したと きの 4 つのスリットの再構成結果を図 $-\mathbf{9}$ に示す。なお,
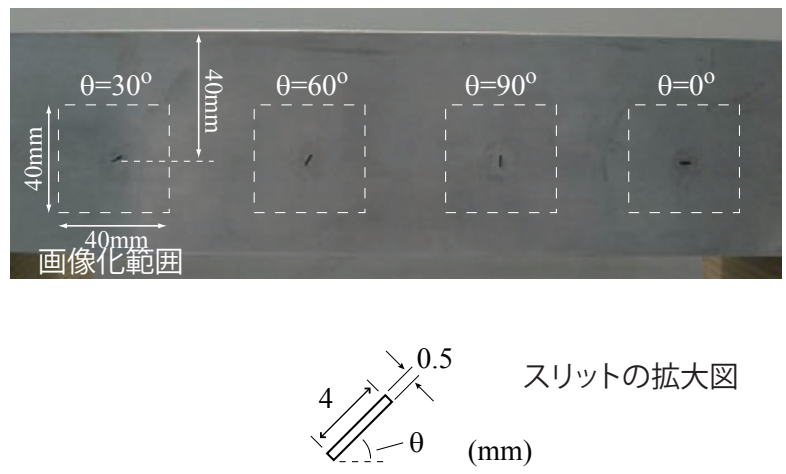

図-8 傾斜角 $\theta$ の異なるスリットを有するアルミニウム試験体
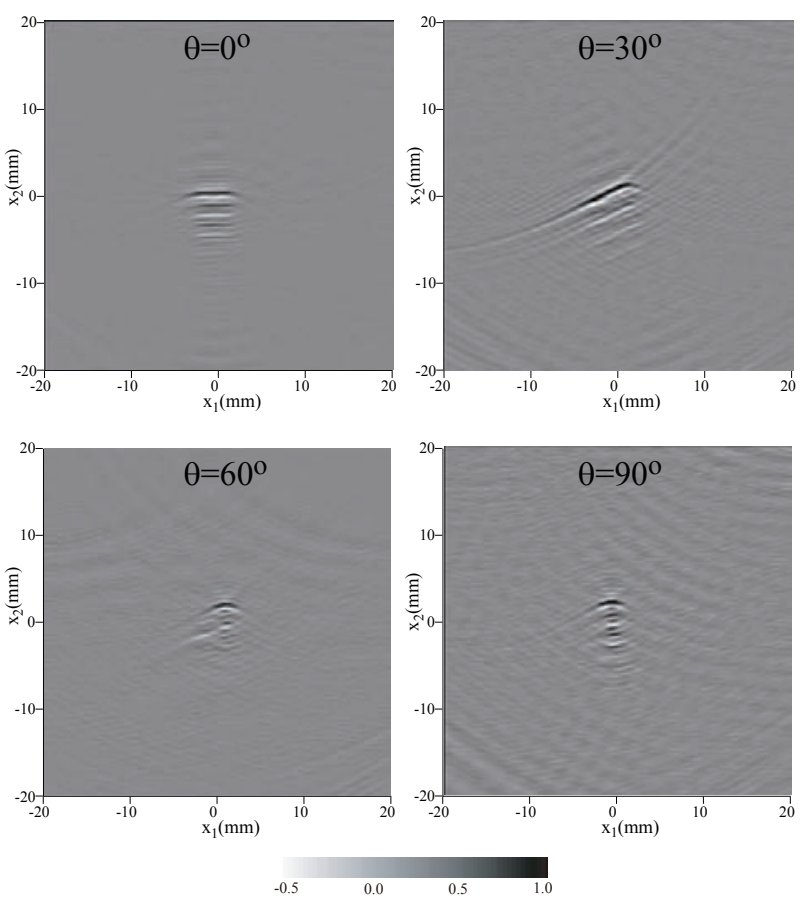

図-9 電子スキャン装置を用いたスリットの形状再構成 (キ ルヒホフ逆散乱イメージング法)

ボルン逆散乱イメージング法はき裂のような面状欠陥 を評価の対象としないので，ここではキルヒホフ逆散 乱イメージング法の結果のみを示している，スリット の傾き $\theta=0^{\circ}$ と $30^{\circ}$ の場合は, スリット全体の形状が 鮮明に表れており, スリット長さの推定が可能である. しかし，スリットの傾きが $\theta=60^{\circ}$ と $90^{\circ}$ の場合はス リットの側面が再構成できておらず，両端部しか確認 できない。これは, スリットの傾きが大きくなると, ス リット側面からの反射波よりも端部からの散乱波が卓 越して受信されるためである.

そこで，次にアレイ探触子をスリットの真上からず らして設置し, 少しでもスリットの側面からの反射波 を受信することで，スリットの全体像を画像化するこ とを試みた。ここでは，図-8に示したスリットのうち 
$\theta=60^{\circ}$ のものに着目し，スリットからアレイ探触子を 離しながら再構成を行った. アレイ探触子の中心からス リットの中心までの間隔を $l$ とし,$l=20 \mathrm{~mm}$ と $30 \mathrm{~mm}$ で計測した場合の再構成結果を図-10に示す. 再構成 結果はアレイ探触子設置面から深さ $40 \mathrm{~mm}$ を中心し て $80 \mathrm{~mm} \times 80 \mathrm{~mm}$ の領域を画像化している. 図-9に 示した $\theta=60^{\circ}$ の結果では，スリットの上側の先端が 強調されて画像化されている. 一方, アレイ探触子の 位置をずらして計測した場合の結果 (図-10)では，ス リット側面からの反射波が多く計測されるため側面形 状とスリットの下側の端部が再構成されつつある。しか しながら, $l=30 \mathrm{~mm}$ の場合はアレイ探触子の真下にス リットがなく，定式化の過程で用いた $1 / \sqrt{r} \approx 1 / \sqrt{\left|y_{2}\right|}$ の近似を満足しなくなるため, 期待したほど再構成結 果が改善されていないのがわかる.この対処法として, 本イメージング法のように素子を 1 つずつ駆動するので はなく, 今後は超音波のビームステアリング14)によっ て斜め方向から集束ビームをスリットに送信する手法 に理論を改良するなどの工夫を行う予定である。

\section{6. 結論}

本研究では, 超音波電子スキャン装置で計測された 欠陥エコーを用いて, 逆散乱イメージング法によるア
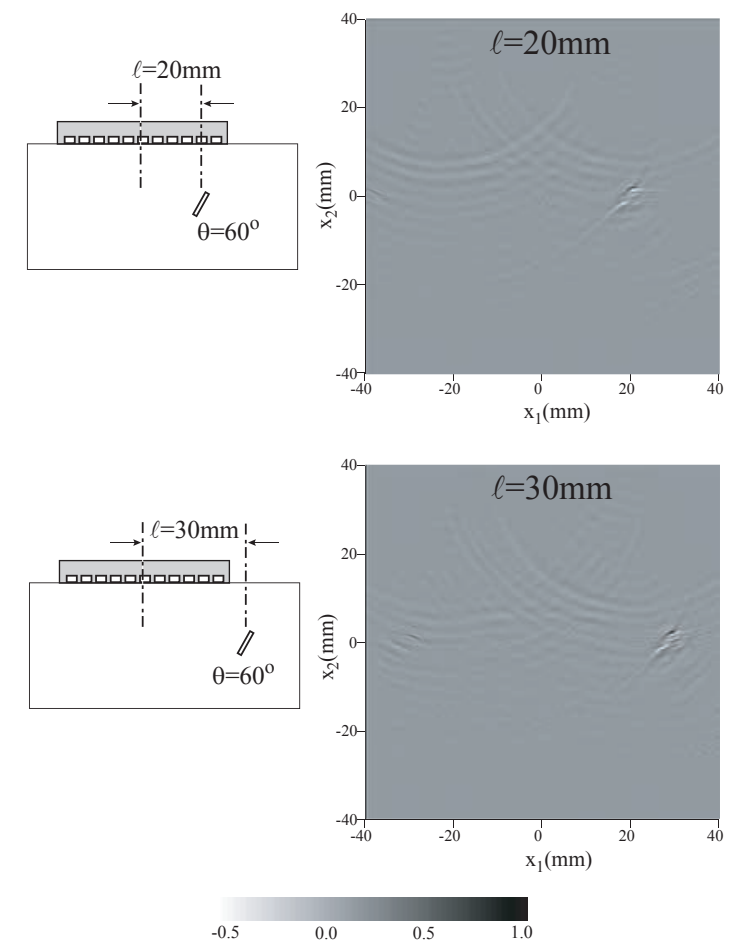

図-10 傾斜角 $\theta=60^{\circ}$ のスリットに対して, アレイ探触子 の中心をずらして超音波を送受信した場合の形状再 構成 $(l=20 \mathrm{~mm}$ と $30 \mathrm{~mm})$
ルミニウム試験体中の人工欠陥の再構成の検証を行っ た。ここでは，計測されたエコーから久陷による散乱 波成分を抽出するデータ処理法を提案し, 波形処理さ れたデータを逆散乱イメージング法にインプットする ことによって久陥形状の再構成を行った。アレイ探触 子は共振ピークを中心に有限な周波数帯域を持つので, 数值シミュレーションのように全周波数帯域で有効な 散乱波データは得られないが, 検出したい欠陥のサイ ズと同程度の波長を有する超音波を送信すれば，欠陥 の再構成が可能であるということが示された. き裂を 模擬したスリットについては，通常はスリット先端部 からのエコーが強いため, 端部のみが再構成されるが, スリット側面からの反射波を多く受信できるように探 触子の位置を変えることで, スリットの全体像が再構 成できる可能性があることを示した。

今後は，マトリクスアレイ探触子を用いて 3 次元逆 散乱イメージング法の検証を行いたいと考えている.

謝辞：本研究は, 科学研究費補助金 (若手研究 $\mathrm{A}$ : 課 題番号 18686038, 代表 中畑和之, および 基盤研究 $(\mathrm{S})$ 課題番号 18106010 , 代表 三木千壽) の補助を受けて行 われました。ここに，記して謝意を表します。

\section{参考文献}

1) 中畑和之, 廣瀬壮一: 超音波リニアアレイ探触子のため の逆散乱イメージング法の開発, 応用力学論文集, Vol.9, pp.107-114, 2006.

2) 中畑和之, 上甲智史, 廣瀬壮一: 逆散乱解析法の超音波 フェーズドアレイ探傷への応用, 応用力学論文集, Vol.10, pp.61-68, 2007.

3）小島正：アレイ探触子，非破壊検査，Vol.51，No.11， pp.705-709, 2002.

4) 横野泰和: フェイズドアレイ UT の適用事例及び標準化 の世界的動向, 非破壊検査, Vol.56, No.10, pp.510-515, 2007.

5) Mostafa, F. and Kak, A.C.: Ultrasonic B-scan imaging: theory of image formation and technique for restoration, Ultrasonic Imaging, Vol.2, pp.1-47, 1980.

6) Mayer, M., Marklein, R., Langenberg, K.J. and Kreutter, T.: Three-dimensional imaging system based on Fourier transform synthetic aperture focusing technique, Ultrasonics, Vol.28, pp.241-255, 1990.

7) Nagai, K.: A new synthetic-aperture focusing method for ultrasonic B-scan imaging by Fourier transform, IEEE Transaction Sonics and Ultrasonics, Vol.SU-32, No.4, pp.531-536, 1985.

8) Kitahara, M., Nakahata, K. and Hirose, S.: Elastodynamic inversion for shape reconstruction and type classification of flaws, Wave Motion, Vol.36, pp.443$455,2002$.

9) Schmerr, L.W. and Song, S.-J.: Ultrasonic Nondestructive Evaluation Systems :Models and Measurements, Springer-Verlag, New York, 2007.

10）高堂谷正樹, 野竹正義, 北原道弘: 定量的非破壊評価一 のニューラルネットワークの適用, 非破壊検査, Vol.42, No.5, pp.230-236, 1993.

11) 中畑和之, 北原道弘: 多点受信波形を用いた逆散乱解析の 
高精度化，土木学会論文集，No.745/I-65，pp.143-153， 2003.

12) 中畑和之，大西正浩，北原道広：線形化逆散乱解析の高 速化と欠陷形状再生一の適用，応用力学論文集，Vol.5， pp.67-74, 2002.
13) Grover, B.R. and Hwang, P.Y.C.: Introduction to Random Signals and Applied Kalman Filtering, John Wiley \& Sons, New York, 1996.

14）河野尚幸，中畑和之，廣瀬壮一：フェーズドアレイ探触 子のモデリングと欠陥エコーのシミュレーション, 日本 機械学会論文集, A 編, 73 巻, 725 号, pp.88-95, 2007.

(2008.9. 3 受付)

\title{
VERIFICATION OF INVERSE SCATTERING IMAGING METHOD BY ULTRASONIC MEASUREMENT WITH ELECTRONIC SCAN DEVICE
}

\author{
Kazuyuki NAKAHATA, Chihiro MATSUOKA and Sohichi HIROSE
}

Inverse scattering imaging methods (ISIMs) conducted with an ultrasonic array transducer have been proposed to reconstruct the geometry of flaws in structural metal components. The ISIMs are based on the linearization technique with the Born and Kirchhoff approximations. The Born-type and Kirchhofftype ISIMs reconstruct the volume and boundary of flaws, respectively. The performance of the ISIMs has already been checked by numerical simulations in our previous studies. In this paper, shape reconstructions of artificial flaws are demonstrated with an electronic ultrasonic scan device. Here we propose a signalprocessing method to extract scattered wave components from measured signals, which are necessary for inputs of the ISIMs. From the imaging results, it is confirmed that the flaw reconstructions are successful for a thin slit as well as drilled holes in aluminum specimens. 